\section{Genetic Diversity and Population Structure of Traditional Greek and Cypriot Melon Cultigens (Cucumis melo L.) Based on Simple Sequence Repeat Variability}

\author{
Emmanouil N. Tzitzikas ${ }^{1}$ \\ Department of Horticultural Genetics and Biotechnology, Mediterranean \\ Agronomic Institute at Chania, P.O. Box 85, Makedonias St. 1, Chania \\ 73132, Greece
}

Antonio J. Monforte

Instituto de Biología Molecular y Celular de Plantas, Consejo Superior de Investigaciones Científicas-UPV, Ciudad Politécnica de la InnovaciónEdificio 8E, Ingeniero Iausto Elio, s/n. 46022 Valencia, Spain

\begin{abstract}
Abdelhak Fatihi
Department of Horticultural Genetics and Biotechnology, Mediterranean Agronomic Institute at Chania, P.O. Box 85, Makedonias St. 1, Chania 73132, Greece
\end{abstract}

\section{Zacharias Kypriotakis}

Technological Education Institute of Iraklion, School of Agricultural Technology, Stavromenos, P.O. Box 140, GR-71110 Iraklion, Greece

Tefkros A. Iacovides and Ioannis M. Ioannides

Molecular Biology Laboratory, Agricultural Research Institute, P.O. Box 22016, 1516, Nicosia, Cyprus

\section{Panagiotis Kalaitzis}

Department of Horticultural Genetics and Biotechnology, Mediterranean Agronomic Institute at Chania, P.O. Box 85, Makedonias St 1, Chania 73132, Greece

Additional index words. microsatellite, molecular marker, genetic diversity, genetic distance, population structure, traditional cultigens, Cucurbitaceae Abstract. Seventeen simple sequence repeat (SSR) markers were used to assess the genetic
diversity and population structure among traditional Greek and Cypriot melon cultigens
(Cucumis melo L.). All SSR markers were polymorphic with a total number of 81 alleles,
whereas all cultigens could be distinguished with at least one SSR, except cultigens 43 and 41 .
Reference accessions showed larger genetic variability with an average of four alleles per locus
and 0.65 gene of diversity compared with an average of 2.47 alleles per locus and 0.30 of gene
diversity for the Greek/Cypriot cultigens. Observed heterozygosity was very low, indicating
a lack of outcrossing, at least in recent times. Unrooted neighbor-joining tree analysis and
population structure analysis clustered the cultigens and the reference genotypes into five
groups. All cultigens could be distinguished; the Cypriot cultigens were more closely related
to the inodorus 'Piel de Sapo', whereas the Greek cultigens were located in an intermediate
position between the inodorus 'Piel de Sapo' and the cantalupensis 'Védrantais'. The cultigen
'Kokkini' was the most divergent among the Greek and Cypriot cultigens. This association
between geographic origin and genetic similarity among Greek and Cypriot cultigens indicates
geographic isolation. Most of the cultivars from the same cultivar group (i.e., inodorus,
cantalupensis) clustered together, but some exceptions were found, suggesting that former
inodorus landraces would have been transformed to cantalupensis as a result of intercrossing
and further selection by farmers. Results of population structure analysis support mixing
between cantalupensis and inodorus. 'Agiou Basileiou', an inodorus cultigen, was assigned to
the subpopulation IV/II of which II is a pure cantalupensis subpopulation. Greek and Cypriot
melon cultigens were developed from a broader germplasm base than western Mediterranean
cultivars and exhibited useful for melon breeding programs genetic variability.

Melon (Cucumis melo L.) origin was traditionally believed to be African (Robinson and Decker-Walters, 1997), although recent

molecular systematic studies suggest that it may be Asian (Renner et al., 2007). Currently, the distribution of wild and cultivated melons is worldwide. A high level of molecular and morphological variability in leaf, plant, and fruit characteristics has been described in melon species (Akashi et al., 2002; Burger et al., 2006; Goldman, 2002; Kirkbride, 1993; Monforte et al., 2003; Stepansky et al., 1999). Melon classification has been progressively evolving by adopting the propositions of many researchers (Jeffrey, 1980; Kirkbride, 1993; Munger and Robinson, 1991; Naudin, 1859; and more recently, Pitrat et al., 2000). Today, it is as follows: there are two major subspecies, melo and agrestis, which are divided even further; the subspecies agrestis into the varietas (varieties): conomon, makuwa, chinensis, acidulus, and momordica; and the subspecies melo into the varietas: cantalupensis, reticulatus, adana, chandalak, amer, inodorus, flexuosus, chate, tibish, dudaim, and chito. The subspecies agrestis is distributed mainly in central and Oriental Asia, whereas the subspecies melo is distributed mainly in the Near East and Mediterranean regions. The primary diversity center of melon is located in central Asia, Iran, Afghanistan, India, Transcaucasia, Turkmenistan, Tajikistan, and Uzbekistan. Far-East Asia and the Mediterranean regions are secondary centers of diversity.

Apart from the significant amount of genetic variability observed among melon germplasm, occidental modern melon cultivars have a relatively narrow genetic base because they belong to a limited number of varietas (mainly inodorus, reticulates, and cantalupensis) (Silberstein et al., 1999).

Various DNA molecular markers have been used to characterize the genetic diversity of melons, including restriction fragment length polymorphism (Zheng et al., 1999), amplified fragment length polymorphism (Garcia-Mas et al., 2000), random amplified polymorphic DNA (RAPD) (Sensoy et al., 2007; Staub et al., 2004), and simple sequence repeat (SSR) (Danin-Poleg et al., 2001), using diverse germplasm from different locations worldwide. Recently, several research groups have focused on the genetic variability among Mediterranean landraces (López-Sesé et al., 2003; Lotti et al., 2008; Sensoy et al., 2007; Staub et al., 2004), which belong to the varietas inodorus, cantalupensis, reticulates, and flexuosus. These reports have shown among traditional landraces an important amount of genetic variability, which has to be systematically classified before their potential use like their introduction in breeding programs.

Among the Mediterranean melon landraces, Greek and Cypriot landraces are not well known. Staub et al. (2004) studied the diversity among Greek melon accessions using RAPD markers, concluding that the Greek germplasm is genetically unique.

In the present work, we used a set of published SSR markers (Danin-Poleg et al., 2001; Fernandez-Silva et al., 2008; Gonzalo et al., 2005) to genetically assess a number of traditional Greek and Cypriot melon cultigens, not tested before, and compare these cultigens with a set of reference accessions to 
increase our understanding of the distribution of genetic variability of melon germplasm in the Mediterranean area.

\section{Materials and Methods}

Plant material and DNA extractions. In this study, 21 different accessions were used: seven Greek and five Cypriot traditional cultigens from geographically diverse areas, two popular in the Cyprus market commercial varieties, and seven reference genotypes. Traditional cultigens were obtained on excursions to small farms in Greece and Cyprus. The two commercial varieties, designated $\mathrm{C} 1$ and $\mathrm{C} 2$, were obtained from a local store in Cyprus. The seven reference genotypes were selected to include a broad spectrum of genetic variability. Details about the origin and classification of accessions into varietas groups are given in Table 1 .

Seeds were germinated at $30{ }^{\circ} \mathrm{C}$ in petri dishes containing wet paper for $6 \mathrm{~d}$. Germinated seeds were planted in pots containing standard pot mixture and transferred into the greenhouse until seedlings developed two or three true leaves, which subsequently were used for DNA extraction.

DNA was extracted as described by Rogers and Bendich (1988) from 10 individual plants per accession. Extracted DNA was quantified with a Hitachi U-2001 spectrophotometer (Hitachi High-Technologies, Tokyo, Japan) and mixed equally at an amount of $50 \mathrm{ng} / \mu \mathrm{L}$. Basic DNA manipulations and molecular techniques were performed according to Sambrook et al. (1989).

Simple sequence repeat genotyping. In this study, 17 SSR markers all previously developed by Danin-Poleg et al. (2001), Fernandez-Silva et al. (2008), or Gonzalo et al. (2005) were used. All SSR markers are found in Table 2. Two sequencing analyzers were used for SSR visualization: the ABI 310 Prism Genetic Analyzer (Applied Biosystems Inc., Foster City, CA) and LI-COR R2 (LI-COR Inc., Lincoln, NE) sequencers.

For ABI 310 visualization, polymerase chain reactions (PCRs) were performed using a DNA Engine Dyad Peltier Thermal Cycler (Bio-Rad Laboratories, Hercules, CA). Forward primers were labeled with a fluorescent dye, 6-FAM ${ }^{\mathrm{TM}}$, TET $^{\mathrm{TM}}$, or $\mathrm{HEX}^{\mathrm{TM}}$ (PE Applied Biosystems Inc., Foster City, CA). All oligos were purchased from MWG-Biotech AG (Ebersberg, Germany). The PCR reactions comprised $60 \mathrm{ng}$ of genomic DNA, 166 $\mu \mathrm{M}$ dNTPs, $0.6 \mu \mathrm{M}$ of each primer, $1 \mathrm{U}$ of Taq polymerase, $1.2 \mu \mathrm{M}$ of $10 \times \mathrm{PCR}$, and $2 \mathrm{mM} \mathrm{MgCl} 2$ buffer and were performed in a final volume of $15 \mu \mathrm{L}$. The cycling conditions were as follows: an initial cycle at $94{ }^{\circ} \mathrm{C}$

\footnotetext{
Received for publication 5 May 2009. Accepted for publication 28 Sept. 2009.

This research was supported by grants No. 3S0052I (FARVALDI project) from the INTERREG III-C Sud Program.

${ }^{1}$ To whom reprint requests should be addressed; e-mailmanolis@maich.gr.
}

for $4 \mathrm{~min}$ followed by 35 cycles at $94{ }^{\circ} \mathrm{C}$ for $30 \mathrm{~s}, 40$ to $60^{\circ} \mathrm{C}$ (depending on primer) for $30 \mathrm{~s}$, and $72{ }^{\circ} \mathrm{C}$ for $1 \mathrm{~min}$. A final cycle was allowed at $72{ }^{\circ} \mathrm{C}$ for $15 \mathrm{~min}$. Samples were run on an ABI Prism 310 Genetic Analyzer. Uncoated capillaries, $47 \mathrm{~cm}$ long with an internal diameter of $50 \mu \mathrm{m}$, and denaturant gel POP-4 ${ }^{\mathrm{TM}}$ (Applied Biosystems Inc., Foster City, CA) were selected for separation of fragments, whereas the Virtual Filter Set C of the GeneScan3.1 software (Applied Biosystems Inc., Foster City, CA) was used for equipment calibration. Amplified PCR products were diluted 1:7 in distilled water. Two microliters of the diluted PCR product were subsequently mixed with $13 \mu \mathrm{L}$ formamide and $0.5 \mu \mathrm{L}$ of molecular standard GeneScan ${ }^{\mathrm{TM}}$ 500 TAMRA (Applied Biosystems Inc., Foster City, CA) denatured at $95{ }^{\circ} \mathrm{C}$ for $3 \mathrm{~min}$ and kept on ice until loading. Loading of the amplified fragments was achieved with 15.0 $\mathrm{kV}$ for $5 \mathrm{~s}$. The fluorochrome-labeled PCR products were electrophoresed at $15.0 \mathrm{kV}$, laser power $9.8 \mathrm{~mW}$, and a temperature of 60 ${ }^{\circ} \mathrm{C}$. Electrophoretic data were analyzed with the standard GeneScan3.1 software (Applied Biosystems Inc.).

A 20-nucleotide sequence from the M13 cloning vector (CACGACGTTGTAAAACG ACC) was attached to the 5-end of the forward primers for visualization using the LI-COR IR2 sequencer. The M13 primer was labeled with either IRD-700 or IRD-800 dyes. PCR reactions were performed in a final volume of $15 \mu \mathrm{L}$ with $1 \times$ Taq buffer $[10 \mathrm{~mm}$ Tris- $\mathrm{HCl}, 50 \mathrm{~mm} \mathrm{KCl}, 0.001 \%$ gelatin $(\mathrm{pH}$ 8.3)], 1.5 to $3.5 \mathrm{~mm} \mathrm{MgCl}_{2}, 166 \mu \mathrm{M}$ dNTPs, 5 pmol of forward and reverse primer, 0.66 pmol of M13-labeled primer, 2 U Taq DNA polymerase, and $20 \mathrm{ng}$ of genomic DNA. The cycling conditions were as follows: an initial cycle at $94{ }^{\circ} \mathrm{C}$ for $4 \mathrm{~min}$ followed by 35 cycles at $94{ }^{\circ} \mathrm{C}$ for $30 \mathrm{~s}, 40$ to $60{ }^{\circ} \mathrm{C}$ (depending on primer) for $30 \mathrm{~s}$, and $72{ }^{\circ} \mathrm{C}$ for 1 min. A final cycle was allowed at $72{ }^{\circ} \mathrm{C}$ for $15 \mathrm{~min}$. Five microliters of loading buffer (95\% formamide, $20 \mathrm{~mm}$ EDTA, $0.05 \%$ bromophenol blue, $0.05 \%$ xylene cyanol) were added to the PCR mix and samples were denatured at $96{ }^{\circ} \mathrm{C}$ for $2 \mathrm{~min}$. Electrophoresis was performed in denaturing conditions at $50{ }^{\circ} \mathrm{C}$ in TBE $(90 \mathrm{~mm}$ Tris-borate, 2 mм EDTA pH 8.0, and 7.5 $\mathrm{M}$ urea) buffer using $6 \%$ polyacrylamide gels (AA:BIS = 19:1). Microsatellite allele sizes were estimated comparing their migration pattern with the IRD-700 or -800 , 50- to 350-bp size standards (LI-COR).

Genetic variability analysis. Analysis of the pooled DNA samples was based on the assumption that the observation of two or more SSR alleles in a single genotype could have resulted from the presence of several heterozygous plants, homozygous plants for the alternative alleles, or a combination of both. Experimental conditions during the PCR amplification did not permit the quantification of the frequency of an SSR allele in the sample based on the band intensity. Therefore, all detected alleles were assumed to have a frequency of $1 / \mathrm{n}(\mathrm{n}=$ number of alleles). Number of alleles, allele frequency, major allele frequency, polymorphism information content (PIC), gene diversity, genetic distances according to Nei et al. (1983), and neighbor-joining (NJ) trees were calculated with PowerMarker 3.25 (Liu and Muse, 2005). The NJ tree was plotted with MEGA 3.0 (Kumar et al., 2004).

The number of populations in our collection was inferred using STRUCTURE 2.2 (Falush et al., 2007; Pritchard et al., 2000). Briefly, several population numbers (from $K=1$ to 11 ) were tested with the software and the $\alpha$ posterior probability for each $K$ recorded. The total number of populations was set for $K$ when the probability reached a plateau for higher $K$.

\section{Results}

Polymorphism among all accessions. All SSR markers were polymorphic with a total number of 81 alleles ranging from two (ECM231) to nine (CMAT89) with an average of 4.76 alleles per locus (Table 2). Major allele frequency had an average of 0.65 (ranging from 0.88 for CMAT35 to 0.31 for CMAT89). Similar trends were observed for gene diversity and PIC variables (Table 2). The number of within-accession polymorphic loci ranged between zero and three (data not shown). All within-accession polymorphic loci showed only two alleles within the accession. One or two polymorphic loci were observed in $23.8 \%$ of the accessions and three alleles only in $5.8 \%$ of the accessions (data not shown). The low variability within accession is reflected by the observed heterozygosity ranging between 0 and 0.20 with an average of 0.052 , being lower than expected for all markers. For five markers (CMCTN35, CMCTN38, ECM122, ECM88, and TJ2), the observed heterozygosity was 0 .

Polymorphism within Greek and Cypriot cultigens and comparison with reference accessions. All SSRs, except TJ31, ECM122 and ECM231, were polymorphic between Greek and Cypriot cultigens. All Greek and Cypriot cultigens could be distinguished with at least one SSR, except 43 and 41, which were different only in one allele for locus ECM81; 43 was heterozygous for this locus, whereas 42 was homozygous.

Table 2 also shows the genetic variability comparison between the Greek and Cypriot traditional cultigens together as a group (Greek/Cypriot) versus the reference accessions. As expected, reference accessions shows a larger genetic variability with an average of four alleles per locus and average gene diversity of 0.65 than the Greek/Cypriot cultigens with 2.47 alleles per locus and gene diversity of 0.30 . Moreover, allelic frequencies were more balanced among reference accessions, which had an average major allele frequency of 0.45 compared with 0.78 , which was the average major allele frequency of Greek/Cypriot cultigens

Phylogenetic relations among melon accessions. The unrooted NJ tree based on the genetic distance by Nei et al. (1983) is 
Table 1. Genetic material used in the study. ${ }^{2}$

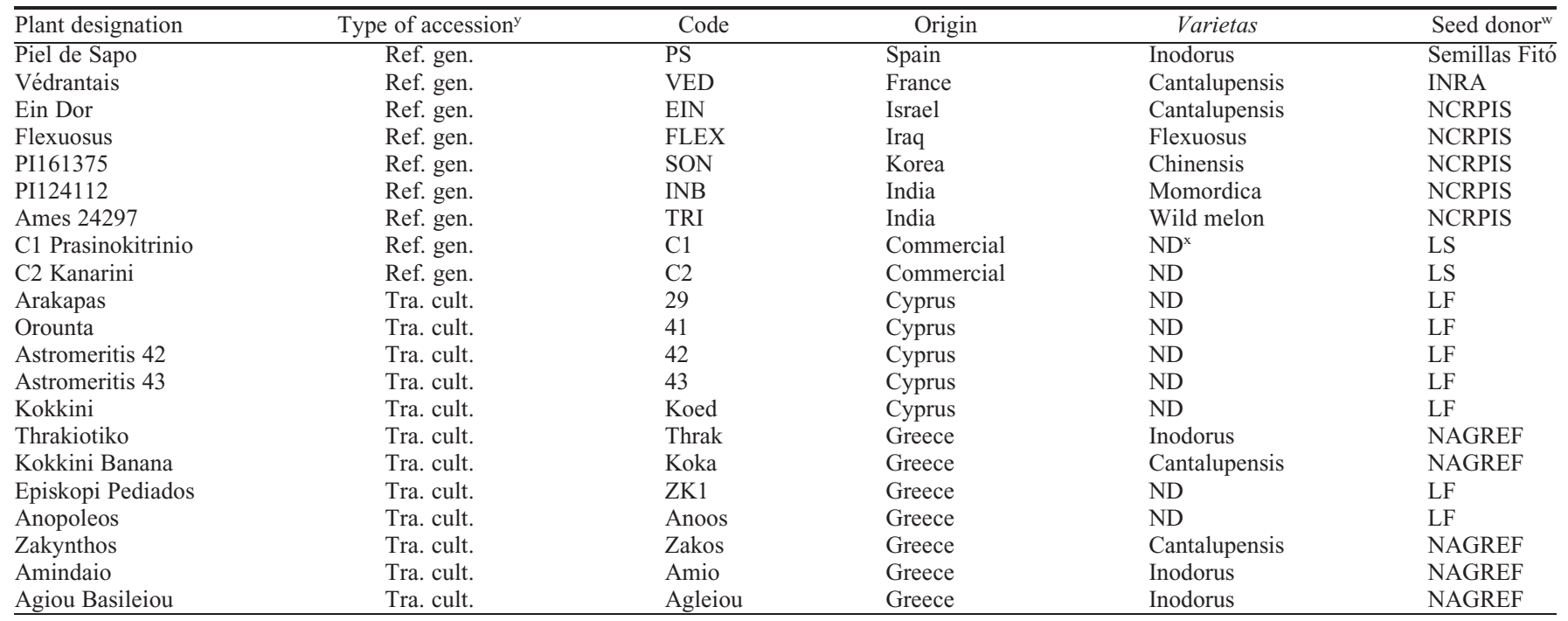

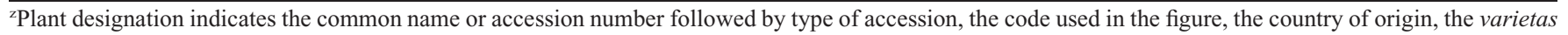
according Pitrat et al. (2000), when known, and the seed donor.

${ }^{\mathrm{y}}$ Ref. gen. $=$ reference genotype; Tra. cult. $=$ traditional cultigen.

${ }^{\mathrm{x} D}=$ not determined.

wSeed donors: Semillas Fitó S.A. (Barcelona Spain); INRA = l'Institut National de la Recherche Agronomique (Avignon, France); NCRPIS = North Central Regional Plant Introduction Station (Ames, IA); LS = local store; LF = local farmer; NAGREF = National Agricultural Research Foundation (Gastouni, Greece).

Table 2. Genetic variability parameters for each simple sequence repeat marker used in this study and their mean calculated with Powermarker 3.25 (Liu and Muse, 2005). ${ }^{\mathrm{z}}$

\begin{tabular}{|c|c|c|c|c|c|c|c|}
\hline Marker & $\begin{array}{l}\text { Sample } \\
\text { size }\end{array}$ & $\begin{array}{l}\text { Allele } \\
\text { number }\end{array}$ & $\begin{array}{c}\text { Genotype } \\
\text { number }\end{array}$ & $\begin{array}{l}\text { Major allele } \\
\text { frequency }\end{array}$ & $\begin{array}{c}\text { Gene } \\
\text { diversity }\end{array}$ & $\begin{array}{c}\text { Observed } \\
\text { heterozygosity }\end{array}$ & $\begin{array}{l}\text { Polymorphism } \\
\text { information conten }\end{array}$ \\
\hline$\overline{\mathrm{CMAG} 128}$ & 21 & 4 & 5 & 0.65 & 0.52 & 0.10 & 0.46 \\
\hline CMTCN41 & 21 & 8 & 7 & 0.62 & 0.59 & 0.05 & 0.57 \\
\hline CMTA134 & 21 & 6 & 7 & 0.67 & 0.53 & 0.10 & 0.50 \\
\hline СMAТ89 & 21 & 9 & 10 & 0.31 & 0.80 & 0.05 & 0.78 \\
\hline TJ31 & 21 & 4 & 4 & 0.83 & 0.29 & 0.05 & 0.28 \\
\hline CMCTN35 & 21 & 4 & 4 & 0.45 & 0.63 & 0.00 & 0.55 \\
\hline CMCTN38 & 21 & 6 & 6 & 0.62 & 0.58 & 0.00 & 0.55 \\
\hline CMAT35 & 21 & 4 & 4 & 0.88 & 0.22 & 0.05 & 0.21 \\
\hline CMAGN75 & 21 & 5 & 5 & 0.67 & 0.51 & 0.05 & 0.47 \\
\hline ECM122 & 21 & 4 & 4 & 0.86 & 0.26 & 0.00 & 0.25 \\
\hline CMAGN79 & 21 & 7 & 7 & 0.55 & 0.65 & 0.05 & 0.61 \\
\hline CMTCN6 & 21 & 3 & 4 & 0.58 & 0.53 & 0.11 & 0.43 \\
\hline ECM231 & 21 & 2 & 3 & 0.88 & 0.22 & 0.05 & 0.19 \\
\hline ECM178 & 21 & 3 & 4 & 0.64 & 0.49 & 0.05 & 0.41 \\
\hline ECM81 & 21 & 4 & 6 & 0.55 & 0.57 & 0.20 & 0.49 \\
\hline ECM88 & 21 & 3 & 3 & 0.50 & 0.55 & 0.00 & 0.46 \\
\hline $\mathrm{TJ} 2$ & 21 & 5 & 5 & 0.81 & 0.34 & 0.00 & 0.32 \\
\hline Mean & 21 & 4.76 & 5.18 & 0.65 & 0.49 & 0.05 & 0.44 \\
\hline \multicolumn{8}{|l|}{ Subdivision } \\
\hline Greek/Cypriot & 14 & 2.47 & 2.82 & 0.78 & 0.30 & 0.06 & 0.26 \\
\hline Reference & 7 & 4.00 & 4.06 & 0.45 & 0.65 & 0.04 & 0.59 \\
\hline
\end{tabular}

${ }^{\mathrm{z}}$ In the bottom of the table, genetic variability parameters of the Greek/Cypriot traditional cultigens versus the reference accessions are also shown.

shown in Figure 1A. The tree depicts the clustering of the Greek cultigens within the Cucumis melo subsp. melo accessions, clearly different from the subsp. agrestis accessions ('SON' and 'INB'). All genotypes were divided into five groups (I to V). Greek and Cypriot cultigens were spread into two subpopulations (IV and V), whereas reference genotypes were divided into subpopulations I, II, and III with the exception of the reference accessions 'EIN' and 'PS', which were grouped into the $\mathrm{V}$ group and the Cypriot cultigen 'Koed' in Group I. Most of the Cypriot cultigens were closely related and close to the inodorus reference genotype 'PS'. Greek accessions were generally lo- cated in an intermediate position between the inodorus 'PS' and the cantalupensis 'VED'.

The population structure was studied with the software STRUCTURE 2.2 (Falush et al., 2007; Pritchard et al., 2000). To estimate the number of populations $(K)$, an analysis was performed with a predefined population number ranking from $K=2$ to 11 whereby the logarithm of the probability of the data $\{\ln [\operatorname{Pr}(\mathrm{X} / \mathrm{K})]\}$ was recorded for each $K$. The maximum $\ln [\operatorname{Pr}(\mathrm{X} / \mathrm{K})]$ was observed for $K=$ 8 , although the differences with $K=5$ to 7 were small (data not shown), i.e., a plateau for $\ln [\operatorname{Pr}(\mathrm{X} / \mathrm{K})]$ was observed at $K=5$. A larger $K$ did not result in any further division within Greek and Cypriot accessions, only between reference genotypes. Thus, $K=5$ was chosen as the final estimated number of populations. The subpopulations inferred by population analysis are depicted in Figure 1B. The $\mathrm{x}$ axis represents the $Q$ value (the estimated membership coefficients for each individual in each subpopulation). Different color segments within each individual indicate the percent representation of each corresponding subpopulation. Y-axis bars represent each accession. Five subpopulations were inferred (I to V); the assignment of individuals to each subpopulation was the same as was shown by the NJ tree. There were three cultigens that had a coefficient $q>0.3$ for two subpopulations and therefore 

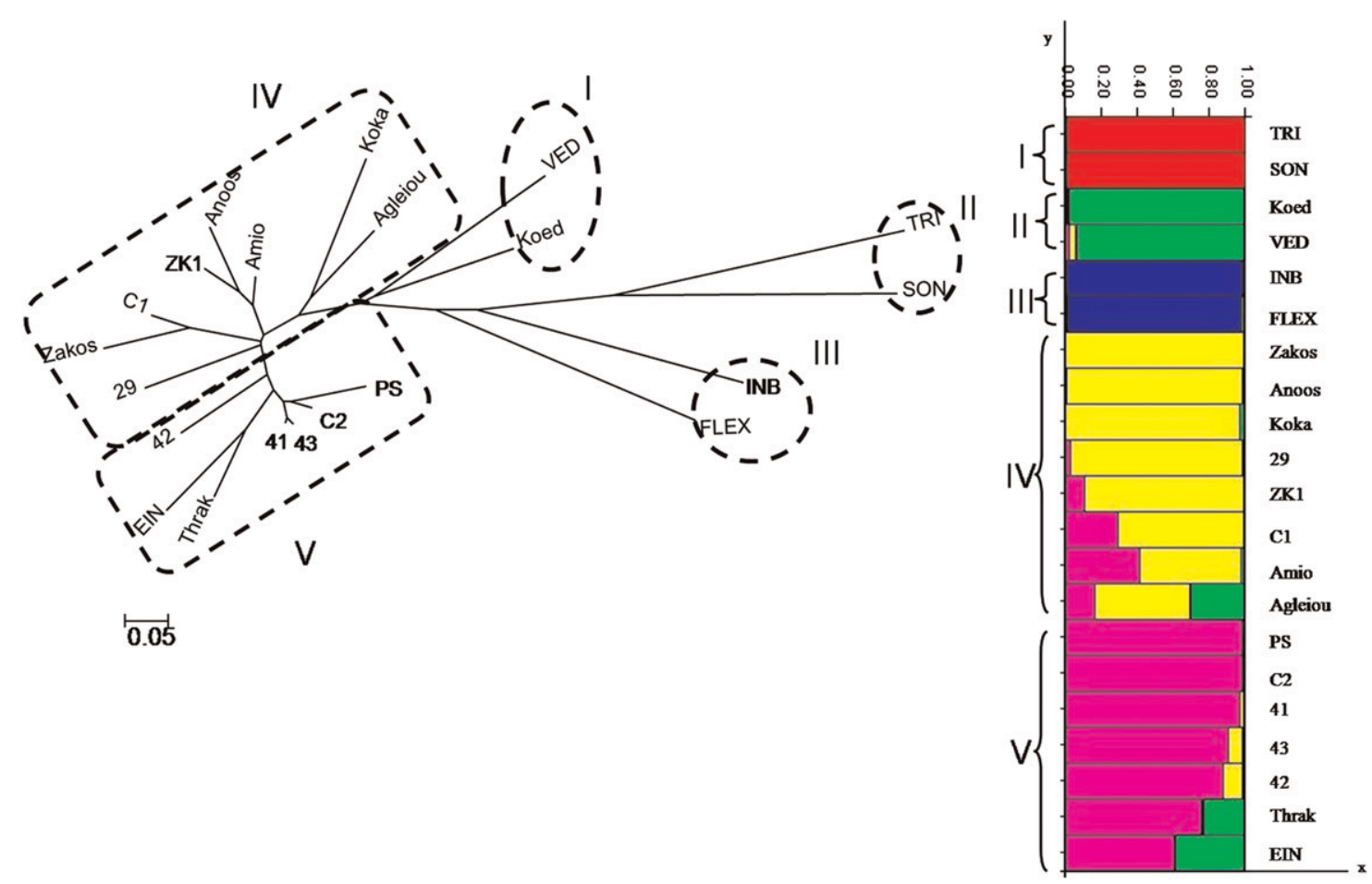

a

b

Fig. 1. (A) The neighbor-joining (NJ) tree based on genetic distance according to Nei et al. (1983). The distance scale is shown at the bottom of the tree. The accessions are coded according to Table 1. (B) Bar plot of population structure estimates of 21 accessions of melon assessed with 18 simple sequence repeat markers. Each accession is represented by a single horizontal bar (y-axis) broken into $K$ colored segments (x-axis) with lengths proportional to $q$ of the $K$ inferred subpopulations. The sum of $q$ values for each accession is one. Accession code names corresponding to each bar are shown on the right side. Latin numbers (I to V) correspond to the predefined subpopulations $(K=5)$.

were assigned into mixed subpopulations. The cultigen 'EIN' was assigned to the subpopulation V/II, the cultigen 'Agleiou' was assigned to the subpopulation IV/II, and the cultigen 'Amio' was assigned to the subpopulation V/IV.

\section{Discussion}

In previous studies, López-Sesé et al. (2003) and Staub et al. (2004) used RAPD markers to characterize a large number of Greek melon germplasm. In this study, we also assessed the genetic diversity of Greek germplasm but focused only on cultigens, including some from Cyprus. All Greek and Cypriot cultigens used in this study were assessed for the first time, except for 'Agleiou' and 'Zakos', which were used as internal references.

For our assessment, the molecular marker-type SSR was used, which to our knowledge is the first time this has been done for either Greek or Cypriot germplasm accessions. The selected SSRs, even relatively small in number (17), were sufficient to distinguish all the tested cultigens. This demonstrates the usefulness of the chosen marker set to study the genetic variability among the analyzed cultigens. The tested cultigens have been primarily developed and maintained by local farmers and, hence, cross-pollination with landraces would be expected, resulting in appreciable levels of heterozygosity. Our results showed very low observed heterozygosity among Greek and Cypriot traditional cultigens indicating lack of intercrossing either between them or with other landraces in recent times. This unexpected result is in agreement with the results of Staub et al. (2004), which are attributed to the small sample sizes examined and/or the use of similar seed lot among related growers. To their assumptions, we add the hypothesis that if outcrossing occurred, farmers have made efforts to maintain the genetic originality of the cultigens, probably to satisfy regional consumer preferences.

Reference accessions showed higher genetic variability compared with the Greek/ Cypriot cultigens. Nevertheless, the genetic variability observed among Greek/Cypriot cultigens is relatively significant compared with reference accessions, because the reduction of gene diversity is only $\approx 50 \%$. These results demonstrate that the Greek and the Cypriot germplasm retain important levels of genetic variability.

The Greek and Cypriot traditional cultigens examined in the present report can be undoubtedly classified within the subspecies melo, very close to western Mediterranean cultivars and different from the flexuosus accession tested. In previous studies, when RAPD markers were used (Staub et al., 2004), Greek flexuosus landraces did not clearly show distinction from Greek inodorus landraces. This difference might be a result of the different germplasm used or the higher power of discrimination of SSR markers compared with RAPDs.

The unrooted NJ tree (Fig. 1A) clustered the tested material into five population groups (I to $\mathrm{V}$ ). The more populated among the five groups were: Group V, including mostly accessions from Cyprus, which were closely related to the inodorus 'Piel de Sapo', and Group IV, including mostly accessions from Greece, which were in an intermediate position between the inodorus 'Piel de Sapo' and the cantalupensis 'Védrantais', indicating that some of them are closer to inodorus types, whereas some were closer to cantalupensis types. This association between geographic origin and genetic affinity among Greek and Cypriot cultigens gives evidence of geographic isolation.

Our results also show that most of the accessions from the same varietas (i.e., inodorus, cantalupensis) cluster together, but some exceptions were found. Among the tested cultigens is the inodorus cultigen 'Agiou Basileiou', which is phenotypically very similar to 'Piel de Sapo', another inodorus cultigen. However, our results, in accordance with the work of López-Sesé et al. (2003) and Staub et al. (2004), placed it relatively distant to the 'Piel de Sapo' types and closer to cantalupensis cultigens. Apparently, farmers selected independently in Spain and Greece for the same phenotypic 
characteristics from a broad ancestral gene pool, producing similar phenotypes obtained from divergent selection. One of the major differences among inodorus and cantalupensis germplasms is the fruit climacteric behavior: inodorus types are nonclimacteric and cantalupensis are climacteric. Recent studies have showed that the manipulation of very few genes can produce severe changes in climacteric behavior (Moreno et al., 2008; Obando-Ulloa et al., 2008; Périn et al., 2002a), opening up the possibility that former inodorus landraces would have been transformed to cantalupensis as a result of intercrossing and further selection by farmers. This transformation cannot be proven by this study. However, the results of STRUCTURE support mixing between cantalupensis and inodorus. 'Agiou Basileiou', an inodorus cultigen, was assigned to the subpopulation IV/II of which II is a pure cantalupensis subpopulation.

Currently, most of the mapping populations used to study the genetic control of fruit traits in melon have been produced using very distant melon genotypes (Eduardo et al., 2007; Monforte et al., 2004; Périn et al., 2002b). Our results suggest the idea that mapping populations from crosses between inodorus and cantalupensis cultivars would reveal whether the differences between these melon types are actually caused by a low number of genes.

In the study by López-Sesé et al. (2003), it was shown that inodorus accessions from Crete are more diverse than Spanish accessions. The genetic relationships among Greek and Cypriot cultigens as depicted in Figure 1 also agree with that observation. One possible explanation is that Greek and Cypriot melon accessions were developed from a broader germplasm base. This is probably a result of a number of flexuosus introductions from the remaining east Mediterranean counties, which, since antiquity, have been known to be an important cultivation center, especially for flexuosus cultigens (Janick et al., 2007).

In summary, the current report using SSR markers reinforces the previous studies of López-Sesé et al. (2003) and Staub et al. (2004) indicating that Greek and Cypriot traditional melon cultigens exhibit unique genetic variability and geographical division.

\section{Literature Cited}

Akashi, Y., N. Fukuda, T. Wako, M. Masuda, and K. Kato. 2002. Genetic variation and phylogenetic relationships in East and South Asian melons, Cucumis melo L., based on the analysis of five isozymes. Euphytica 125:385-396.

Burger, Y., U. Sa'ar, H.S. Paris, E. Lewinsohn, N. Katzir, Y. Tadmor, and A.A. Schaffer. 2006. Genetic variability for valuable fruit quality traits in Cucumis melo. Isr. J. Plant Sci. 54:233-242.

Danin-Poleg, Y., N. Reis, G. Tzuri, and N. Katzir. 2001. Development and characterization of microsatellite markers in Cucumis. Theor. Appl. Genet. 102:61-72.

Eduardo, I., P. Arus, A.J. Monforte, J. Obando, J.P. Fernandez-Trujillo, J.A. Martinez, A.L. Alarcon,
J.M. Alvarez, and E. van der Knaap. 2007. Estimating the genetic architecture of fruit quality traits in melon using a genomic library of near isogenic lines. J. Amer. Soc. Hort. Sci. 132:80-89.

Falush, D., M. Stephens, and J.K. Pritchard. 2007. Inference of population structure using multilocus genotype data: Dominant markers and null alleles. Mol. Ecol. Notes 7:574-578.

Fernandez-Silva, I., I. Eduardo, J. Blanca, C Esteras, B. Picó, F. Nuez, P. Arús, J. Garcia-Mas, and A.J. Monforte. 2008. Bin mapping of genomic and EST-derived SSRs in melon (Cucumis melo L.). Theor. Appl. Genet. 118: 139-150.

Garcia-Mas, J., M. Oliver, H. Gomez-Paniagua, and M.C. de Vicente. 2000. Comparing AFLP, RAPD and RFLP markers for measuring genetic diversity in melon. Theor. Appl. Genet. 101:860-864.

Goldman, A. 2002. Melons for the passionate grower. Artisan, New York, NY.

Gonzalo, M.J., M. Oliver, J. Garcia-Mas, A Monfort, R. Dolcet-Sanjuan, N. Katzir, P. Arús, and A.J. Monforte. 2005. Simple-sequence repeat markers used in merging linkage maps of melon (Cucumis melo L.). Theor. Appl. Genet. 110:802-811.

Janick, J., H.S. Paris, and D.C. Parrish. 2007. The cucurbits of Mediterranean antiquity: Identification of taxa from ancient images and descriptions. Ann. Bot. (Lond.) 100:1441-1457.

Jeffrey, C. 1980. A review of the Cucurbitaceae. Bot. J. Linn. Soc. 81:233-247.

Kirkbride, J.H. 1993. Biosystematic monograph of the genus Cucumis (Cucurbitaceae). Botanical identification of cucumbers and melons. Parkway Publishers Inc., Boone, NC.

Kumar, S., K. Tamura, and M. Nei. 2004. MEGA3: Integrated software for molecular evolutionary genetics analysis and sequence alignment. Brief. Bioinform. 5:150-163.

Liu, K.J. and S.V. Muse. 2005. PowerMarker: An integrated analysis environment for genetic marker analysis. Bioinformatics 21:21282129.

López-Sesé, A.I., J.E. Staub, and M.L. GómezGuillamón. 2003. Genetic analysis of Spanish melon (Cucumis melo L.) germplasm using a standardized molecular-marker array and geographically diverse reference accessions. Theor. Appl. Genet. 108:41-52.

Lotti, C., A.R. Marcotrigiano, C. de Giovanni, P. Resta, A. Ricciardi, V. Zonno, G. Fanizza, and L. Ricciardi. 2008. Univariate and multivariate analysis performed on bio-agronomical traits of Cucumis melo L. germplasm. Genet. Resources Crop Evol. 55:511-522.

Monforte, A.J., J. Garcia-Mas, and P. Arus. 2003. Genetic variability in melon based on microsatellite variation. Plant Breed. 122:153-157.

Monforte, A.J., M. Oliver, M.J. Gonzalo, J.M Alvarez, R. Dolcet-Sanjuan, and P. Arus. 2004. Identification of quantitative trait loci involved in fruit quality traits in melon $(\mathrm{Cucu}$ mis melo L.). Theor. Appl. Genet. 108:750758.

Moreno, E., J.M. Obando, N. Dos-Santos, J.P. Fernandez-Trujillo, A.J. Monforte, and J. Garcia-Mas. 2008. Candidate genes and QTLs for fruit ripening and softening in melon. Theor. Appl. Genet. 116:589-602.

Munger, H.M. and R.W. Robinson. 1991. Nomenclature of Cucumis melo L. Cucurbit. Gen. Coop. Rep. 14:43-44.
Naudin, C.V. 1859. Essais d'une monographie des espèces et des variétés du genre Cucumis. Ann. Sci. Nat. Bot. Sér. 4,11:5-87.

Nei, M., F. Tajima, and Y. Tateno. 1983. Accuracy of estimated phylogenetic trees from molecular data. II. Gene frequency data. J. Mol. Evol. 19:153-170.

Obando-Ulloa, J.M., E. Moreno, J. Garcia-Mas, B. Nicolai, J. Lammertyn, A.J. Monforte, and J.P. Fernandez-Trujillo. 2008. Climacteric or non-climacteric behavior in melon fruit-1. Aroma volatiles. Postharvest Biol. Technol. 49: 27-37.

Périn, C., M.C. Gomez-Jimenez, L. Hagen, C. Dogimont, J.C. Pech, A. Latche, M. Pitrat, and J.M. Lelievre. 2002a. Molecular and genetic characterization of a non-climacteric phenotype in melon reveals two loci conferring altered ethylene response in fruit. Plant Physiol. 129: 300-309.

Périn, C., L.S. Hagen, V. de Conto, N. Katzir, Y. Danin-Poleg, V. Portnoy, S. Baudracco-Arnas, J. Chadoeuf, C. Dogimont, and M. Pitrat. 2002b. A reference map of Cucumis melo based on two recombinant inbred line populations. Theor. Appl. Genet. 104:1017-1034.

Pitrat, M., P. Hanelt, and K. Hammer. 2000. Some comments on infraspecific classification of cultivars of melon. Acta Hort. 510:29-36.

Pritchard, J.K., M. Stephens, and P. Donnelly. 2000. Inference of population structure from multilocus genotype data. Genetics 155:945959.

Renner, S.S., H. Schaefer, and A. Kocyan. 2007. Phylogenetics of Cucumis (Cucurbitaceae): Cucumber (C. sativus) belongs in an Asian/ Australian clade far from melon (C. melo). BMC Evol. Biol. 7:58-69.

Robinson, R.W. and D.S. Decker-Walters. 1997. Cucurbits. Cab International, New York, NY.

Rogers, S.O. and A.J. Bendich. 1988. Extraction of DNA from plant tissues. Plant Mol. Biol. Man. A $6: 1-10$.

Sambrook, J., E.F. Fritsch, and T. Maniatis. 1989. Molecular cloning: A laboratory manual. 2nd Ed. Cold Spring Harbor Laboratory Press, Cold Spring Harbor, NY.

Sensoy, S., S. Büyükalaca, and K. Abak. 2007. Evaluation of genetic diversity in Turkish melons (Cucumis melo L.) based on phenotypic characters and RAPD markers. Genet. Resources Crop Evol. 54:1351-1365.

Silberstein, L., I. Kovalski, R. Huang, K. Anagnostou, M.M.K. Jahn, and R. Perl-Treves. 1999. Molecular variation in melon (Cucumis melo L.) as revealed by RFLP and RAPD markers. Sci. Hort. 79:101-111.

Staub, J.E., A.I. López-Sesé, and N. Fanourakis. 2004. Diversity among melon landraces ( $\mathrm{Cucu}$ mis melo L.) from Greece and their genetic relationships with other melon germplasm of diverse origins. Euphytica 136:151-166.

Stepansky, A., I. Kovalski, and R. Perl-Treves. 1999. Intraspecific classification of melons (Cucumis melo L.) in view of their phenotypic and molecular variation. Plant Syst. Evol. 217: 313-332.

Zheng, X.Y., D.W. Wolff, S. Baudracco-Arnas, and M. Pitrat. 1999. Development and utility of cleaved amplified polymorphic sequences (CAPS) and restriction fragment length polymorphisms (RFLPs) linked to the Fom-2 fusarium wilt resistance gene in melon $(\mathrm{Cucu}$ mis melo L.). Theor. Appl. Genet. 99:453463. 